\title{
FORMAÇÃO CONTINUADA DE PROFESSORES QUE ENSINAM MATEMÁTICA NA INFÂNCIA: reflexões conceituais e práticas
}

\author{
IN SERVICE TEACHERS EDUCATION TEACHING MATHEMATICS \\ IN CHILDREN: conceptual and practical reflections
}

\author{
FORMACIÓN CONTINUADA DE PROFESSORES QUE ENSEÑAM \\ MATEMÁTICA EN LA INFANCIA: reflexiones conceptuales y prácticas
}

\author{
Sandra Aparecida Fraga da Silva \\ Professora Doutora do Instituto Federal do Espírito Santo (IFES) \\ Serra-ES, Brasil. \\ sandrafraga7@gmail.com \\ Dilza Côco \\ Professora Doutora do Instituto Federal do Espírito Santo (IFES) \\ Serra-ES, Brasil. \\ dilzacoco@gmail.com
}

\begin{abstract}
Resumo: $O$ presente artigo tem por objetivo evidenciar apropriação de conhecimentos matemáticos e práticas educativas enunciadas por professores em atividades de formação continuada, desenvolvida a partir da Perspectiva Histórico-Cultural. Essas atividades foram realizadas em 2015 e 2016, por meio da oferta de três cursos de extensão no Instituto Federal do Espírito Santo Campus Vitória1', com o objetivo de discutir com professores dos anos iniciais questões sobre o processo de ensino e aprendizagem de matemática na infância. Participaram professores da rede pública de ensino que atuam na educação infantil ou nos anos iniciais do Ensino Fundamental. Todas as três ações estiveram vinculadas a pesquisas de mestrado vinculadas ao Educimat orientadas pelas autoras deste artigo, e articulam ensino, pesquisa e extensão. Nestas atividades investigamos o movimento formativo dos sujeitos na apropriação de conhecimentos e como estes evidenciam influências em seu trabalho. Para isso assumimos o conceito de atividade pedagógica como unidade dialética que possibilita estruturar as tarefas de formação de modo a envolver o professor em atividade de estudo e atividade de ensino. As análises concluem que as tarefas de formação apresentadas evidenciam potencialidades formativas para promover o desenvolvimento profissional do professor numa dimensão coletiva, dialógica, onde a apropriação de conhecimentos possibilita uma nova qualidade para as ações de ensino dos participantes.
\end{abstract}

Palavras-chave: formação docente. Atividade pedagógica. Conhecimentos matemáticos. Infância.

\begin{abstract}
The present article aims at evidencing the appropriation of mathematical knowledge and educational practices enunciated by teachers in activities of in service teacher education, developed from the Historical-Cultural Perspective. These activities were carried out in 2015 and 2016, through the offer of three extension courses, with the aim of discussing with teachers of the initial years questions about the teaching and learning process of mathematics in childhood. Participants were teachers from the public education system who work in early childhood education or in the initial years of Elementary School. All three actions were linked to master degree's research guided by the authors of this article, and articulated teaching, research and extension tasks. In these activities we investigate the formative movement of the subjects in the appropriation of knowledge and how these evidences influences in their work. For this case, we assume the concept of pedagogical activity as a dialectical unit that makes it possible to structure the training tasks to involve the teacher in study activity and teaching activity. The analyzes conclude that the training tasks presented evidenced the formative potential to promote the professional development of the teacher in a collective, dialogical, where the appropriation of knowledge allows a new quality for the teaching actions of the participants.
\end{abstract}

Keywords: Teacher training. Pedagogical activity. Mathematical knowledge. Childhood.

Resumen: El presente artículo tiene por objetivo mostrar la apropiación de conocimientos matemáticos y prácticas educativas expresadas por profesores en atividades de formación continuada, desarrollada a partir de la Perspectiva Historico-Cultural. Estas atividades se realizaron en 2015 y 2016, a través de la oferta de tres cursos de extensión, con el objetivo de discutir com profesores de los años iniciales questiones sobre el proceso de enseñanza y aprendizaje de matemáticas en la infancia. Participaron professores de la red pública de la enseñanza que actúan en la educación infantil o en los años iniciales del nível primário. Las três acciones estuvieron vinculadas a investigaciones de maestria orientadas por las autoras de este articulo, y articulan enseñanza, investigación y extensión. En estas actividades investigamos el movimiento formativo de los sujetos en la apropiación de conocimientos y cómo estos influyen en su

\footnotetext{
1 Essas ações apresentadas neste trabalho participaram de um projeto mais amplo financiado pela Fapes, a qual agradecemos o financiamento.
} 
trabajo. Para ello assumimos el concepto de actividad pedagógica como unidad dialéctica que posibilita estructurar las tareas de formación de modo a involucrar al profesor en actividad de estúdio y actividad de enseñanza. Los análisis concluyen que las tareas de formación presentadas evidencian potencialidades formativas para promover el desarrollo profesional docente en una dimensión colectiva, dialógica, donde la apropiación de conocimientos posibilita una nueva calidad para las acciones de enseñanza de los participantes.

Palabras claves: formación docente. Actividad pedagógica. Conocimientos matemáticos. Infancia.

\section{INTRODUÇÃO}

A formação de professores no Brasil constitui temática de discussão antiga e recorrente, especialmente, pela crescente demanda das camadas populares pelo direito a educação, mas mesmo assim ainda se constitui como desafio para pesquisadores de todas as áreas. Segundo Saviani (2009), referências à necessidade de formação de professores podem ser identificadas desde a Lei de Escolas de Primeiras Letras, aprovada em outubro de 1827. Posteriormente, várias outras iniciativas foram processadas para institucionalização da formação de professores, sendo a mais recente a promulgação da Lei de Diretrizes e Bases da Educação Nacional 9.394/1996, um marco legal importante para colocar a formação de professores no âmbito do ensino superior. Vinculada a essa tendência, a aprovação da Lei 11.892/2008, que criou os Institutos Federais (IFs), instaurou novo lócus de formação de professores, quando estabelece a exigência de vinte por cento das vagas dessas instituições destinadas a cursos de licenciatura.

A partir desse último instrumento legislativo, a rede federal sofreu significativo processo de ampliação e diversificação de áreas de atuação. No Instituto Federal do Espírito Santo - Ifes, identificamos no período entre 2008 a 2017, o acréscimo de doze para vinte e dois campi, distribuídos em todas as microrregiões do estado, atendendo necessidades educativas oriundas de diversos arranjos produtivos. Essa expansão de unidades viabilizou maior atuação no campo da formação de professores, pois vários campi passaram a ofertar cursos de licenciatura, bem como cursos de mestrados profissionais na área de ensino.

No campus Vitória no qual atuamos, as primeiras iniciativas foram inauguradas com a formação de professores de matemática. O primeiro curso de graduação em licenciatura nessa área foi iniciado em 2008, e posteriormente, no ano de 2011, a instituição recebeu a aprovação do curso de mestrado profissional em Educação em Ciências e Matemática - Educimat - na área de Ensino. A criação desses dois cursos potencializou ações de grupos de pesquisas que se dedicam à discussões, estudos, investigações e atividades de extensão voltadas à formação de professores. No nosso grupo de pesquisa em Práticas Pedagógicas de Matemática - Grupem, também buscamos trabalhar com professores que ensinam matemática para a infância.

Neste artigo, desenvolvemos análises de dados produzidos em três experiências de formação continuada de professores, coordenadas pelo Grupem. Essas análises têm por objetivo evidenciar indícios de apropriação de conhecimentos matemáticos e de práticas educativas enunciadas por professores em atividades de formação continuada desenvolvida a partir da Perspectiva HistóricoCultural. Tais ações foram sistematizadas nos anos de 2015 e 2016, e articularam a tríade ensino, pesquisa e extensão. A proposta foi desenvolvida por meio da oferta de três cursos de extensão, com o objetivo de discutir com professores dos anos iniciais questões sobre o processo de ensino e aprendizagem de matemática na infância. Colocamos infância pois tratamos dos anos iniciais de maneira mais abrangente, incluindo professores que atuam na educação infantil. Tais ações privilegiaram estudos sobre conhecimentos de geometria, grandezas e medidas e número racional na sua representação fracionária. Foram desenvolvidas a partir da integração entre pesquisadores do Ifes, mestrandos, licenciandos de matemática e professores da rede pública de ensino.

Entendemos que a motivação e objetivos que mobilizaram o encontro desses diferentes sujeitos, preocupados e interessados no ensino de conhecimentos matemáticos, encontram unidade teóricoprática na noção de trabalho docente a partir de discussão e reflexão da Atividade Pedagógica. Compreendemos Atividade pedagógica da mesma maneira como Araújo e Moraes (2017, p. 51), numa perspectiva da educação escolar e de que "como uma prática social e coletiva, insere-se no processo de desenvolvimento psíquico de cada pessoa". Assim, assumimos a investigação da pesquisa em Educação na direção de compreender a Atividade pedagógica nessa dimensão 
de desenvolvimento humano e necessária para a apropriação de conhecimento produzido pela humanidade. Compreendemos que na "Atividade Pedagógica, esses conhecimentos devem ser prioritariamente os conhecimentos teóricos" (ARAÚJO; MORAES, 2017, p. 53).

Para organizarmos melhor nossos aportes teóricos, na próxima sessão deste texto, focalizamos discussões sobre essa noção de formação docente a partir da abordagem Histórico-Cultural. Em seguida, apresentamos um panorama das atividades desenvolvidas nas três ações formativas, bem como o público envolvido. Na última sessão, explicitamos os dados que sinalizam o movimento de formação, realçando episódios que indicam a integração entre atividade de estudo e de ensino que evidenciam a unidade do processo de formação e suas repercussões para o processo de apropriação de conhecimentos dos sujeitos participantes bem como em seus relatos sobre práticas de sala de aula.

\section{PERSPECTIVA HISTÓRICO-CULTURAL E FORMAÇÃO DE PROFESSORES: contribuições e pressupostos}

O desenvolvimento de pesquisas e ações no campo da formação inicial e ou continuada de professores demanda o alinhamento com uma abordagem teórico-metodológica. Nesse sentido privilegiamos o diálogo com a Teoria Histórico-Cultural (THC), cujos pressupostos foram elaborados por Vigotski e seus colaboradores, grupo conhecido como Troika. Entendemos que conceitos oriundos dessa abordagem colaboram para o delineamento de ações formativas que tomam como eixo estruturante a atividade principal do docente, ou seja, o trabalho pedagógico. Para compreendermos tal proposição, é importante desenvolvermos discussões sobre o lócus onde ocorre esse trabalho, bem como sua natureza, a função da mediação inerente a ação de ensinar, e também o modo de organização do ensino e suas relações com o conhecimento e com os instrumentos. Dessa maneira, "a formação docente assim entendida implica a articulação entre motivos e sentidos na atividade de ensino, permitindo que as ações planejadas e desencadeadas sejam coerentes com o que move o sujeito professor a agir: ensinar" (MORETTI; MOURA, 2011, p. 436).

Pesquisadores de diferentes áreas têm se filiado aos pressupostos da THC e oferecido contribuições para discussões desses aspectos, como Saviani (2008), Duarte (2016), Martins (2015), Marsíglia (2011) e Asbahr (2011). Especificamente sobre a formação de professores dos anos iniciais que ensinam matemática na infância, podemos encontrar diálogo com produções de Moura (1996; 2000), Lopes (2004), Moretti (2007), Araújo (2003), Cedro (2008) e ainda em âmbito internacional, as produções de Radfor (2016), da Laurentin University/Canadá. Essas produções e muitas outras oferecem aporte para adensar a compreensão sobre possibilidades de percursos formativos de professores que ensinam matemática numa perspectiva humanizadora e que investiga a pesquisa em Educação a partir da análise da Atividade Pedagógica. Segundo Araújo e Moraes (2017, p. 53-54):

A pesquisa sobre Atividade Pedagógica direciona-se à produção de uma síntese téorico-prática a respeito das ações formativas necessárias para se efetivar as bases do desenvolvimento do pensamento teórico - que envolve a reflexão, a análise, e o plano interior das ações.

Partindo da ideia de que a escola é o lugar em nossa sociedade onde privilegiadamente se desenvolve o trabalho do professor (RIGON; ASBAHR; MORETTI, 2016), e sua função primordial consiste na socialização do saber sistematizado, em suas formas mais elaboradas para compartilhar com as novas gerações, podemos entender que a formação desses profissionais necessariamente precisa estabelecer conexões com essa realidade concreta da escola a partir de discussões sobre a Atividade Pedagógica. Essas conexões podem ser visualizadas a partir das demandas do trabalho docente, pois o ensinar e aprender coloca professores e estudantes em relação com 0 conhecimento produzido pela humanidade a partir de problemas reais. Nessa perspectiva, a atividade de ensinar exige que o professor tenha conhecimento aprofundado de um determinado assunto e o seu movimento histórico de constituição para que o objetivo do seu trabalho seja alcançado, ou seja, contribuir com a aprendizagem dos estudantes e intervir em seu desenvolvimento. Assim, a formação do professor pode ser compreendida como processo que possui uma unidade dialética entre atividade de ensino e atividade de estudo, pois o professor aprende para ensinar e ao ensinar possibilita que o estudante aprenda. 
Sobre essa unidade dialética, Moura (2012) nos mostra que é na atividade pedagógica que encontramos a síntese desses elementos. Para ele, o professor ao organizar de maneira intencional situações de ensino encontra motivos para estudar, pois quanto mais conhece o assunto a ser ensinado poderá encontrar ou criar uma melhor forma de mediar os conhecimentos aos estudantes com vista à constituição do pensamento teórico. Desse modo, a motivação para o estudo do professor encontra sintonia com o objetivo do trabalho. Nesse caso, realiza um trabalho imaterial, porque o resultado de sua ação "[...] revela-se na promoção da humanização dos homens, na consolidação de condições facilitadoras para que os indivíduos se apropriem do saber historicamente sistematizados pelo gênero humano" (MARTINS, 2015, p. 4).

$\mathrm{Na}$ formação de professores, esses motivos de diferentes professores se unem a partir de relações sociais que são estabelecidas num movimento formativo. Esse processo fica evidente nos objetivos das atividades de ensino e na busca pelos professores por espaços de formação continuada. Notamos que ações de formação se constituem como formas de apropriações de experiências sociais, num processo educativo contínuo "que pode ocorrer consciente e outras vezes inconscientemente, direta ou indiretamente, intencional ou não intencionalmente" (FRANCO; LONGAREZI, 2011, p.561). Porém, percebemos que, quando este processo é intencional e consciente o professor, juntamente com seus pares, se apropria desses conhecimentos teóricos e de suas formas de desenvolvimento e realiza uma relação direta entre teoria e prática, tornando o movimento formativo como um processo coletivo.

\begin{abstract}
Sendo a educação um processo coletivo, é no compartilhar que o docente tem a oportunidade de apropriar-se de novos conhecimentos, pois, embora as ações possam ser de cada um daqueles que concretizam uma determinada atividade, a aprendizagem não acontece no que cada um deles faz de forma isolada, mas na interação entre sujeitos ou entre sujeitos e objetos. Assim, faz-se necessário que as ações sejam desenvolvidas por todos, mas que cada um tenha não só a oportunidade, mas o comprometimento de participar (LOPES et al., 2016, p.25).
\end{abstract}

Nesse âmbito, o professor precisa compreender que no processo formativo na perspectiva Histórico-Cultural sua ação precisa organizar-se a partir de sua atividade principal, seu trabalho, sua atividade de ensino. Essa atividade não pode ocorrer de forma alienada, pois a ação do professor está diretamente ligada com o conhecimento (RIGON; ASBAHR; MORETTI, 2016). Compreendemos que essa discussão acerca do trabalho do professor em sua Atividade de Ensino é necessária para pensarmos a formação de professor, pois, segundo Moura (2012)

Estar em atividade de ensino, implica, portanto, em ser consciente na ação de ensinar. Isto é, implica em intencionalidade da ação educativa. Consciência que é acima de tudo, a de ser pertencente a uma comunidade cuja ação tem por finalidade propiciar a apropriação da cultura humana, ou mais objetivamente, a apropriação de ferramentas simbólicas capazes de permitir aos sujeitos os meios necessários para viverem plenamente em sociedade (MOURA, 2012, p. 185).

Vinculado a essas discussões, Moura et. al (2010) desenvolve o conceito de atividade orientadora de ensino (AOE). Para os autores,

O ensino tomado como atividade, como o concebe Leontiev - com um caráter de processo social, mediado por instrumentos e signos, e estruturado com base em uma necessidade -, exige um modo especial de organização. A qualidade de atividade do ensino dá-se pela necessidade de proporcionar a apropriação da cultura, que pode mobilizar os sujeitos a agirem para a concretização de um objetivo comum: o desenvolvimento das potencialidades humanas para a apropriação e o desenvolvimento de bens culturais (linguagem, objetos, ferramentas e modo de ação). É esse modo especial de organizar o ensino, em que objetivos, ações e operações se articulam como atividade, que dá à AOE a dimensão de unidade formadora do estudante e do professor, ao concretizarem a apropriação da cultura no contexto de educação escolar. Assim, a qualidade da mediação da AOE a caracteriza como um 
ato intencional, o que imprime uma responsabilidade ímpar aos responsáveis pela educação escolar (MOURA et. al, 2010, p. 99).

Essa responsabilidade pela intencionalidade das ações de ensino sinaliza ao professor que a atividade de mediação dos conhecimentos científicos demanda a compreensão do seu movimento histórico-lógico de constituição. Desse modo, a partir de questões advindas da natureza de seu trabalho, o professor necessita apropriar-se do conceito que deseja ensinar, em sua dinamicidade histórica manifestada na produção cultural e não apenas em sua forma mais acabada. Essas pontuações indicam a importância de espaços de formação coletivos, onde o docente tenha possibilidade de aprimorar conhecimentos e dialogar com seus pares sobre as especificidades do processo de ensino.

Além dessa demanda de estudos dos conceitos, Moura et. al (2016) defendem o ensino a partir da organização de situações desencadeadoras de aprendizagem (SDA). Para o autor essas SDA podem ser estruturadas com base na resolução de problemas o que pode favorecer o envolvimento dos sujeitos à busca por conhecimentos científicos que colaboram para a solução da problemática apresentada. Essas situações desencadeadoras podem ser sistematizadas a partir de histórias reais, virtuais, ou jogos que envolvam o conceito a ser apropriado. Para os autores, sob essas condições os estudantes mobilizam esforços de resolução, explicitam hipóteses e discutem coletivamente, tendo possibilidade de desenvolver o pensamento teórico.

Na Atividade Pedagógica precisamos realizar ações que desenvolvam tanto o pensamento empírico, necessário para que a formação dos conceitos, como o pensamento teórico (DAVIDOV, 1988). Na Teoria Histórico-Cultural entendemos que a escola é o lugar propício para o trabalho com os conhecimentos teóricos científicos organizados pela humanidade. Para que isto ocorra, é necessário que os professores se apropriem desse pensamento teórico e compreenda os processos de produção e apropriação para que, intencionalmente, possa organizar sua Atividade de Ensino de forma a propiciar o aluno em sua Atividade de Aprendizagem. Como estamos trabalhando com formação continuada de professores que ensinam matemática na infância precisamos compreender bem o pensamento empírico, pois, segundo Davidov (1988, p. 109, tradução nossa), esse o "processo de ensino, do pensamento discursivo empírico é uma tarefa obrigatória e importante". Para ele, os professores precisam organizar ações que ajudem os alunos no pensamento autônomo e que leve à compreensão do pensamento geral. Precisamos ainda pensar nas experiências dos alunos, Davidov (1988, p. 111, tradução nossa) afirma que esta ação "deve ser utilizada no ensino, porém em via de sua reestruturação qualitativa dentro de uma forma, especial e nova para o aluno, do conhecimento teórico científico". A formação de professores precisa ajudar o professor a pensar em suas ações e como podem organizar suas Atividades de Ensino ampliando esse uso das experiências iniciais e sociais.

A aproximação com esse conjunto de proposições formuladas a partir de pressupostos da Teoria Histórico-Cultural tem subsidiado a organização de nossas ações de formação continuada com professores dos anos iniciais que ensinam matemática. No percurso das três experiências realizadas, buscamos desenvolver situações formativas que evidenciassem relações entre pensamento teórico e concreto como um elemento importante a ser considerado no processo de planejamento do ensino da matemática. No próximo tópico, delinearemos as características das ações realizadas, para em seguida explicitarmos os episódios de formação que julgamos significativos para retratar as ações formativas.

\section{EXPERIÊNCIAS DE FORMAÇÃO CONTINUADA DE UM INSTITUTO FEDERAL}

Desde 2015, o Instituto Federal do Espírito Santo, por meio do Grupem, tem ofertado cursos de extensão na área de formação de professores, direcionados ao público de professores que ensinam matemática nos anos iniciais. Tais ações foram planejadas a partir de diferentes experiências anteriores das coordenadoras do grupo de pesquisa, autoras do trabalho, com formações e participação em grupos de estudos junto a professores que trabalham nos anos iniciais do ensino fundamental e na educação infantil. Essas experiências anteriores indicaram a necessidade de ações de formação que promovessem discussões e estudos de diferentes conceitos matemáticos ensinados nesses níveis de escolarização. A partir dessa constatação, organizamos ações que envolvessem a tríade pesquisa, ensino e extensão, como destacamos anteriormente. Nessa perspectiva, desenvolvemos 
com mestrandas do programa de Pós-Graduação em Educação, Ciências e Matemática ações de extensão que integraram o processo de produção de dados e análises dessas pesquisas. Dessa maneira, trabalhamos, por meio da pesquisa, com professores de escolas públicas interessados na apropriação de conteúdos necessários ao ensino de matemática para a infância.

Diferentes estudos como de Gatti e Barreto (2009) indicam a necessidade de se desenvolver investigações em formações de professores que ensinam matemática para a infância. Notamos também que existe uma necessidade de realizar formações com base no conceito de práxis, envolvendo o professor em situações formativas que não separam teoria e prática. Silva (2009) destaca que professoras dos anos iniciais que participam de grupos de estudos conseguem se apropriar de conceitos matemáticos que, em geral, não foram trabalhados em suas formações iniciais e que dessas participações decorrem aprendizagens docentes. Além disso, defendemos que a participação num grupo de estudos promove a formação numa perspectiva coletiva, na qual o professor faz parte e participa ativamente do processo de apropriação do conhecimento por meio dos estudos e de suas repercussões no trabalho educativo (MOURA, 2000).

A partir dessa identificação, o Grupem responsável pela coordenação das ações de extensão, selecionou alguns conteúdos indicados por professores dos anos iniciais como necessários para aprofundamento. A partir dessa seleção, no ano de 2015, desenvolvemos dois cursos. O primeiro foi sobre geometria, que iremos denominar de pesquisa 1 (SOUZA, 2016b) e o segundo abordou conhecimentos de Grandezas e Medidas, e será identificado por pesquisa 2 (SOUZA, 2016a). Um detalhe interessante é que no âmbito do ensino organizamos trabalhos de Iniciação científica de licenciandos de matemática para acompanharem esses cursos. Evidenciamos que nessa perspectiva, tanto as mestrandas como os licenciandos participavam ativamente do processo de planejamento, produção e avaliação dos cursos.

No ano de 2016, ofertamos a terceira proposta de formação continuada nesses moldes, e a temática central dessa formação foi sobre números racionais em sua representação fracionária. Essa ação, denominada de pesquisa 3, contou com o envolvimento de três mestrandas com pesquisas em desenvolvimento e com interesse em três aspectos distintos do processo de formação. Uma buscou analisar a proposta de formação em suas características gerais investigando apropriações de professores sobre ideias relacionadas às frações, a segunda concentrou atenção em aprendizagens de um grupo de quatro professoras que participam, além do curso de extensão, de um grupo de estudos por um longo tempo, ou seja, as atividades de estudos já era uma constante na rotina dessas professoras. A última mestranda dedicou-se a investigar as atividades e a importância dos materiais manipuláveis para o ensino de frações como instrumentos de mediação entre os sujeitos e o conteúdo.

Ressaltamos que esses cursos estão inseridos num projeto de pesquisa mais amplo aprovado por uma Fundação de Amparo à Pesquisa do Espírito Santo - Fapes, intitulado "Laboratório de matemática - LEM do IFES/Vitória: atividades, reflexões e formação de professores" e coordenado por uma das autoras deste texto. Os cursos de extensão foram trabalhados a partir de encontros presenciais e atividades desenvolvidas à distância, no ambiente moodle institucional. Um diferencial das formações continuadas oferecidas nesse projeto, é que em todas as ações as professoras e os professores envolvidos assumiam como demanda elaborar, desenvolver e relatar tarefas de ensino a partir das discussões estabelecidas na formação continuada. A seguir, apresentamos no quadro 1 dados dos respectivos cursos. É importante frisar que as inscrições nos cursos foram realizadas por meio de editais públicos disponibilizados na página da instituição, o que gerou um quantitativo significativo de interessados além da capacidade de atendimento do instituto, especialmente pelas características das propostas de formação que demandavam interação e diálogo entre os participantes.

Quadro 1- Dados dos cursos de extensão

\begin{tabular}{|l|c|c|c|c|}
\hline \multicolumn{1}{|c|}{ Curso } & Período & $\begin{array}{c}\text { Número de } \\
\text { inscritos }\end{array}$ & $\begin{array}{c}\text { Número de } \\
\text { professores } \\
\text { matriculados }\end{array}$ & $\begin{array}{c}\text { Número de } \\
\text { professores } \\
\text { concluintes }\end{array}$ \\
\hline Geometria nos anos iniciais do ensino fundamental & $22 / 06$ a 31/08/15 & 110 & 18 & 9 \\
\hline $\begin{array}{l}\text { Contação de histórias e matemática: relações possíveis no } \\
\text { ensino de grandezas e medidas }\end{array}$ & $14 / 09$ a 23/11/15 & 160 & 21 & 18 \\
\hline Redescobrindo Frações e seus significados & $05 / 09$ a 30/11/16 & 154 & 22 & 22 \\
\hline
\end{tabular}

Fonte: Elaborado pelos autores. 
Pelos dados do quadro 1, notamos a alta procura pelos cursos de extensão, o que mostra a necessidade e interesse dos professores pelas ações de formação que tematizam questões relacionadas ao ensino de matemática para a infância. Percebemos também que no primeiro curso teve uma desistência de metade dos professores matriculados. Esse fato pode ser explicado por diferentes motivos, como a falta de atenção do inscrito para a modalidade do curso que era semipresencial, pois alguns professores selecionados não compareceram por entenderem que 0 curso seria à distância, outros por não se adequar a nossa proposta de formação, que diferencia de outras nas quais os professores atuam de forma passiva, pois o formador é o sujeito que desenvolve todo o conteúdo e os cursistas 'assimilam'.

Em nossas ações de formação, as atividades desenvolvidas buscam envolver os professores a participarem do processo de apropriação do conhecimento, além de relacionarem com suas demandas de trabalho pedagógico, quando planejam e desenvolvem atividades de ensino. Essa forma de organizar as ações formativas está ancorada em proposições da perspectiva HistóricoCultural, que concebe a formação numa dinâmica de ação coletiva (MOURA, 2000).

As três pesquisas desenvolvidas foram vinculadas aos pressupostos da abordagem qualitativa de pesquisa, as quais estavam focalizadas na compreensão do processo formativo, com uma proposta de "apreensão da realidade", não apenas de maneira empírica, mas como "um ponto de partida que se apresenta determinado pelos princípios teórico-metodológicos que organizam a análise" (ARAUJO; MORAES, 2017, p. 63). Assim, "a ação de apreender a realidade refere-se fundamentalmente à ação de revelar o fenômeno em seu próprio processo de desenvolvimento, condição fundamental para se determinar os aspectos essenciais do fenômeno em questão" (ARAUJO; MORAES, 2017, p. 62). Dessa maneira, compreendemos o processo formativo em seu processo de mudança, a partir de discussões de conhecimentos matemáticos e suas formas de desenvolvimento em sala de aula a partir das Atividades de ensino dos professores participantes.

Esse processo formativo é trabalhado a partir de compreensão dos participantes de sua atividade de ensino, que pode ser entendido também a partir de Sannino (2011) quando destaca dois princípios epistemológicos deste tipo de pesquisa: o princípio funcional da dupla estimulação e o da ascensão do abstrato ao concreto. Ambos fundamentados na Teoria Histórico-Cultural. Sobre o princípio da ascensão do abstrato ao concreto nossos estudos dialogam também com proposições de Damiani (2012) que defende:

As intervenções que realizamos podem ser vistas como um passo no processo de ascensão do abstrato ao concreto: elas representam o momento de aplicação das abstrações teóricas (no caso, as ideias de Vygotsky sobre ensino/aprendizagem) para entender a realidade concreta (problemas de ensino e aprendizagem a serem sanados), testando sua pertinência e posteriormente produzindo um concreto pensado (entendimento do processo de ensino inovador e suas possibilidades), teorizado (DAMIANI, 2012, p. 6-7).

Essa apropriação do concreto para o abstrato, organizando o abstrato concreto para o concreto pensado, é a base do materialismo histórico dialético de Marx (1978). Para evidenciar tais aspectos presentes em nossas ações de formação, apresentamos episódios produzidos em cada um dos cursos ofertados, como nossas ações formativas contribuíram para que os professores participantes realizassem apropriação de conhecimentos.

A análise dos dados produzidos nos cursos de extensão toma como base a noção de episódios a partir de Moura (2000, p. 59) quando define que "são ações reveladoras do processo de formação dos sujeitos". Identificar esses episódios de formação e organizá-los é importante porque

Os episódios de formação poderão revelar como os sujeitos constroem seus esquemas estratégicos, gerados pela necessidade de resolver problemas definidos pelo coletivo e que são colocados em movimento nas inter-relações entre os conhecimentos práticos. Estes, graças a articulação entre planejamento da ação e reflexão sobre a ação, garantem a interdependência dos fenômenos do objeto "formação", que poderão fazer com que o sujeito em processo constante de formação articule esquemas práticos e estratégicos na concretização das ações educativas (MOURA, 2000, p. 63-64).

$\mathrm{Na}$ sequência deste texto, apresentamos cada curso, seus objetivos e identificamos os episódios de formação pelos quais analisamos os dados posteriormente. O primeiro curso sobre 
geometria teve seu motivo nas aproximações da mestranda $1 \mathrm{com}$ a formação proposta pelo Plano Nacional de Alfabetização na Idade Certa - PNAIC - e na participação em um grupo de estudos no qual professoras dos anos iniciais indicavam que tinham dificuldades em abordar geometria em suas aulas de matemática (SOUZA, 2016b). O curso foi pensando a partir de oficinas que promovia discussões sobre conceitos geométricos a partir do uso de materiais manipulativos e atividades investigativas. O episódio de formação escolhido para visualizar essa ação de formação mostra discussões sobre figuras planas e suas definições, mais especificamente sobre triângulo. Também apresentamos falas de professoras avaliando o curso e destacando mudanças de visão sobre o conteúdo abordado e influências em suas práticas.

No segundo curso, o objetivo foi abordar a interface entre literatura infantil e matemática, mais especificamente com foco em conhecimentos de grandezas e medidas (SOUZA, 2016a). A formação desenvolvida em oficinas tinha sempre atividades dinâmicas envolvendo literatura infantil e arte em contação de histórias e, outra parte de discussão dos conceitos matemáticos envolvidos. O episódio de formação escolhido para exemplificar dados produzidos nessa experiência foi o que envolveu as professoras na questão sobre o que podemos medir. Ao final, destacamos uma ação de uma professora que relata uma prática realizada a partir do curso envolvendo este processo da medida.

Em 2016, realizamos a oferta do terceiro curso intitulado Redescobrindo frações e seus significados, cujo objetivo foi abordar os diferentes significados de frações a partir de resoluções de problemas e discussão de conceitos. Trabalhamos com o termo frações compreendendo que neste nível de ensino se refere ao número racional representado em sua forma fracionária. $O$ episódio formativo escolhido para este trabalho foi uma discussão sobre o que é o inteiro, quando falamos do significado de parte-todo na fração. Enunciados que integram esse episódio evidenciam reflexões em que os professores tiveram oportunidade de estabelecer relações entre concreto e o abstrato. O relato da prática selecionado apresenta uma situação de ensino na qual a professora destaca a ampliação de sua abordagem a partir do curso de formação.

Destacamos que, em todos os cursos, os professores tiveram esclarecimentos sobre as relações das ações de formação com as atividades de pesquisa, bem como foram explicitados os procedimentos de cumprimento dos princípios éticos inerentes à pesquisa na área de ciências humanas. Todos os participantes assinaram os Termos de consentimento livre e esclarecido (TCLE) e Autorização de uso de imagem e voz. As atividades das três ações formativas foram acompanhadas pelas autoras deste artigo e coordenadoras das formações e contou com a parceria de mestrandas, licenciandos e professores das escolas públicas. É importante situar que a medida que os cursos foram desenvolvidos, algumas adaptações foram sendo sistematizadas a fim de qualificar o processo de formação numa perspectiva coletiva.

\subsection{Episódio 1: Discutindo Definições e Conceitos de Polígonos}

Dentre os diferentes momentos do curso de geometria, escolhemos discussões sobre definições de polígonos como nosso episódio ilustrativo de formação em um de seus movimentos. Destacamos que as discussões não aconteceram num mesmo dia, mas dão visibilidade ao fenômeno, pois apresentam "ações reveladoras do processo de formação dos sujeitos participantes de um isolado" (MOURA, 2000, p. 59).

Já tínhamos discutido sobre sólidos geométricos, suas classificações e propriedades. Dessa discussão nos encontros iniciais surgiu a necessidade de investigar conceitos relacionados à geometria plana. Assim, no $4 .^{\circ}$ encontro, realizado em $3 / 8 / 2015$, fizemos questionamentos sobre algumas definições de polígonos, em especial de triângulos. Essa atividade baseou-se em estudos desenvolvidos por Silva (2009), na qual mostra que há um diálogo com jogo de palavras e características necessárias para definir bem um polígono, n nosso caso o triângulo. Ao analisar a pesquisa de Silva (2009), notamos a necessidade de utilizar contraexemplos para mostrar as professoras que seus argumentos ou propriedades eram necessárias, mas não suficientes para definir triângulos. O diálogo a seguir apresenta como esse processo de interação que foi desenvolvido no curso. 
Figura 1 - Exemplo de figura com três lados.

Mestranda 1: o que é um triângulo?

Cármen: três ângulos, né.

Mestranda 1: é uma figura que tem 3 ângulos. Só?

Ana: iguais.

Carla: não, porque depende do triângulo, não?

Mestranda 1: Se a gente fosse dar uma definição?

(áudio pesquisa 1-3/8/2015.) Figura 1
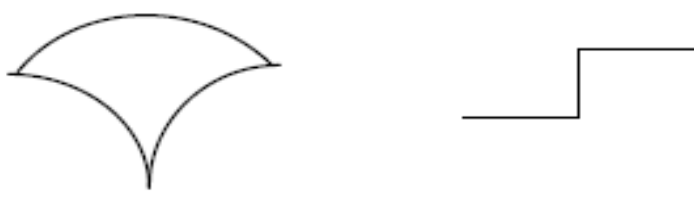

Fonte: Silva (2009)

A mestranda desenhou no quadro figuras com três lados, mas com lados curvos e figuras abertas, que não representavam triângulos na geometria euclidiana plana. Após o desenho, continuamos a discussão.

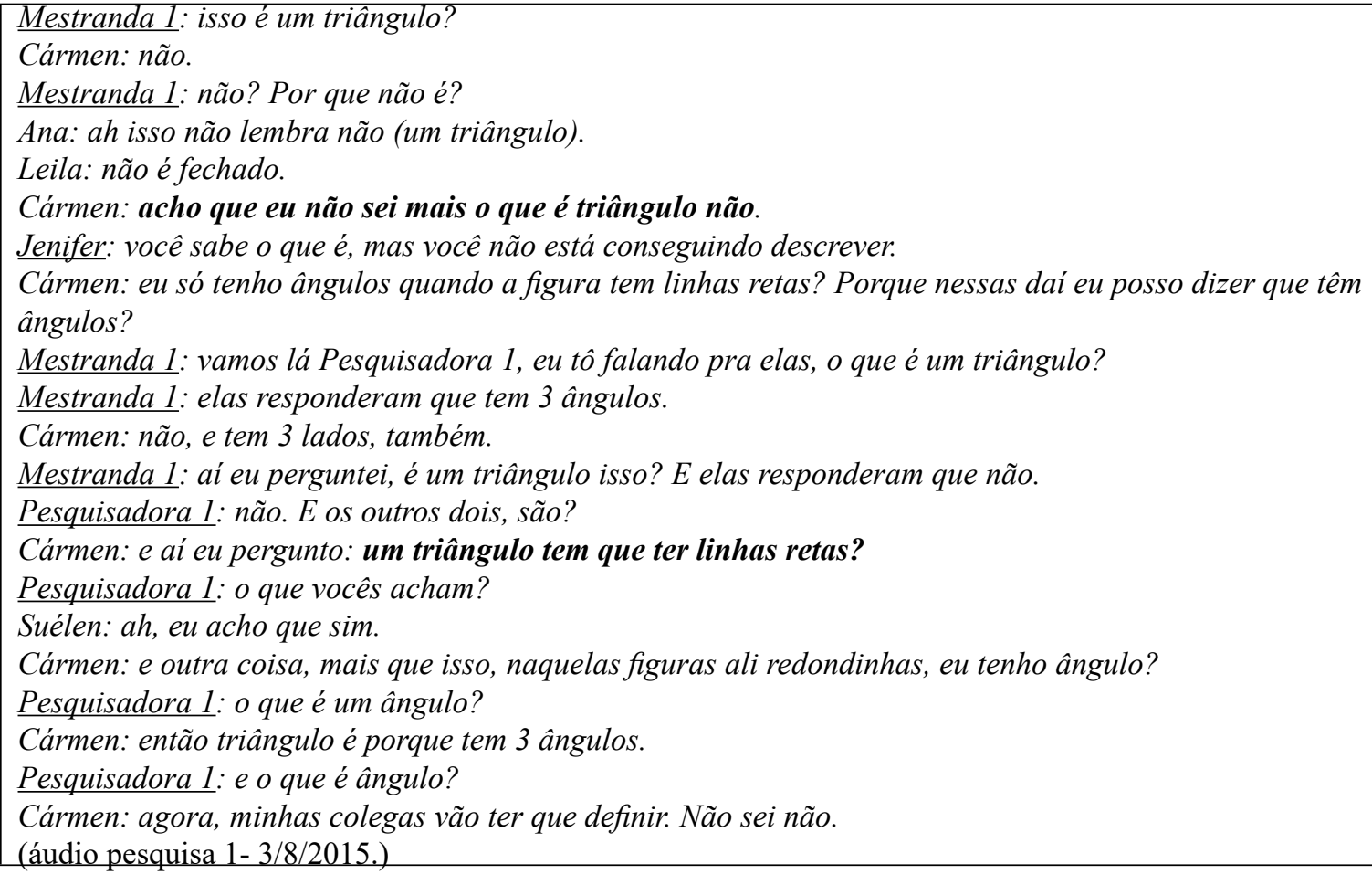

Percebemos que a discussão conceitual de escrever a definição correta não foi fácil, porque, normalmente, os conceitos científicos não são trabalhados de maneira adequada. Ficando apenas o conhecimento empírico, as ideias a partir da visualização e das percepções mais imediatas, como o fato do triângulo ter três lados. Mas de que forma são estes lados? Pode ser de qualquer maneira? Essa discussão ajuda a compreensão do que foi organizado como conhecimento científico pela humanidade. Essa constatação destaca o que Davidov (1988, p. 104, tradução nossa) aponta como um problema da teoria do conhecimento que "consiste em definir, justamente a peculiaridade e as particularidades qualitativas dos conceitos científicos as diferenças dos conceitos cotidianos e empíricos". As professoras destacavam em suas definições noções comuns, cotidianas sobre o triângulo.

No momento do encontro, a partir das discussões outros conceitos foram aparecendo, assim, notamos a necessidade de compreender e definir ângulo. Quando questionamos o que seria um ângulo, uma professora precisou pensar no concreto empírico para chegar ao abstrato. Recorreu à quina da mesa e, com gestos (fig. 2), explicou o que imaginava ser um ângulo. Na sequência, começou a explicar. 
Figura 2 - Professora mostrando o que entendia por ângulo

\begin{tabular}{|l|l|}
\hline Leila: olha aqui um ângulo! \\
Pesquisadora 1: e o que é isso que você tá fazendo? \\
Leila: é o percurso. \\
Suélen: é o espaço de uma ponta a outra. \\
Cármen: de um lado a outro. \\
(áudio pesquisa $1-3 / 8 / 2015)$. \\
\end{tabular}

Fonte: Souza (2016b)

Notamos que a dinâmica proposta propicia que professora se coloque num processo de organização do pensamento buscando relações entre abstrato e concreto, utilizando características sensoriais e empíricas, próprias do pensamento empírico para pensar no conceito de ângulo. Para demonstrar uma ideia mais clara do conceito discutido, ainda utilizando um concreto como ponto de partida, a professora se levanta e vai até a porta para explicar o que entende por ângulo (fig. 3 e 4). Para isso, necessita realizar movimento com a porta, abrindo e fechando. Continuando o diálogo, a Pesquisadora 1 questiona a professora, novamente, em relação a definição de ângulo. Mais uma vez, notamos o cotidiano e situações empíricas presente na ação da professora. Gostaríamos de deixar claro que não estamos menosprezando o conhecimento empírico, mas afirmando que num processo formativo precisamos coletivamente organizar o pensamento científico, para que assim, as professoras possam, intencionalmente, organizar suas ações em sala de aula (MOURA et. al, 2010). O pensamento empírico é importante, principalmente por estarmos trabalhando com formação de professores que ensinam matemática na infância. Segundo Davidov (1988, p. 109, tradução nossa) "a formação nos escolares de menor idade, no processo de ensino, do pensamento discursivo empírico é uma tarefa obrigatória e importante, entretanto, o 'entendimento' entra necessariamente nas formas mais desenvolvidas de pensamento, transmitindo conceitos de precisão e determinação".

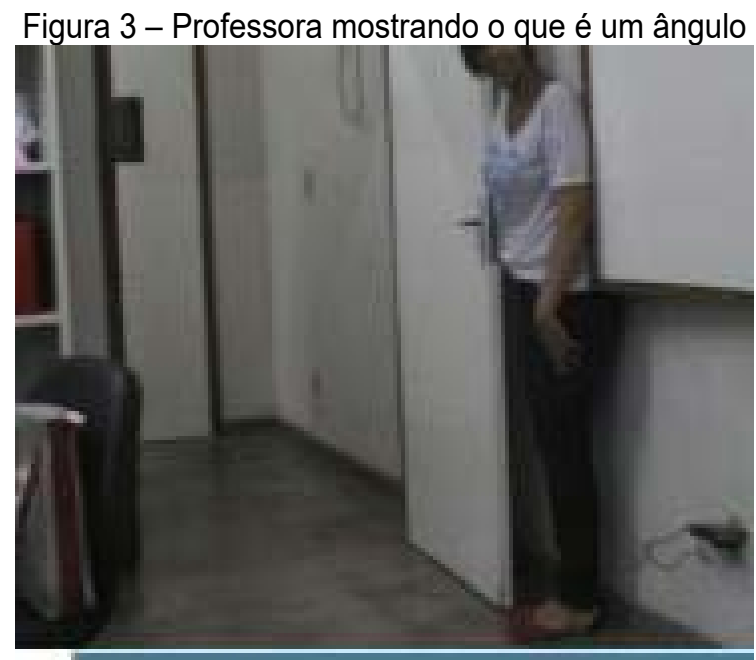

Fonte: mestranda 1 (2016, p. 143)
Figura 4 - Continuação do movimento da porta para mostrar um ângulo

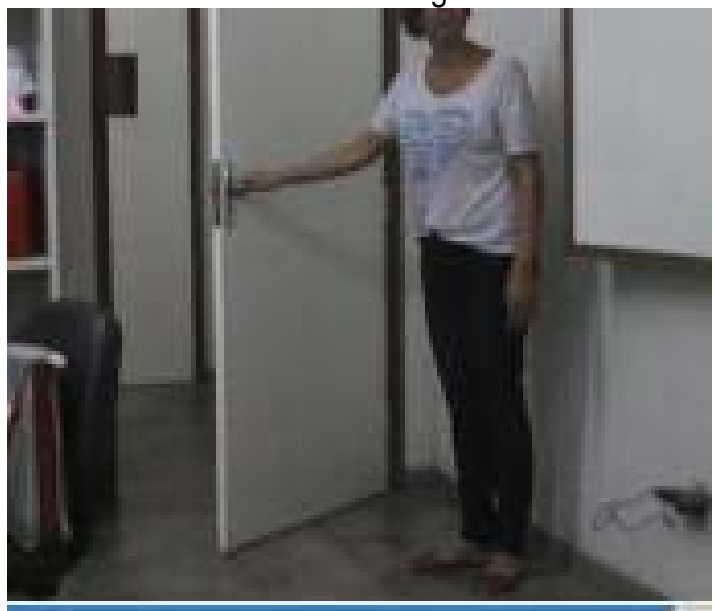

Fonte: mestranda 1 (2016, p. 143) 
Leila: peraí, eu abri aqui, isso é um ângulo. (Abre a porta).

Pesquisadora 1: o que é um ângulo?

Leila: esse trajeto. Aí aqui tem um ângulo. O ângulo é de 90 graus.

Pesquisadora 1: e se deixasse ela na metade? Tem um ângulo também?

Leila: é, 45 graus.

Daniele: igual estacionamento.

Jenifer: estacionamento?

Pesquisadora 1: vaga de estacionamento. Tem vaga a 45 graus.

Daniele: é a vaga meio tortinha.

[...]

Pesquisadora 1: mas você tá vendo como tem várias palavras da geometria que a gente fala, a gente usa, mas a gente não sabe o conceito? E essas coisinhas simples e complexas ao mesmo tempo, é simples porque a gente pensa no cotidiano, é complexa porque a gente pensa no conceito.

Suélen: e carrega isso pro resto da vida e não sabe nem o que que é.

Daniele: não é medida do encontro de retas?

[...]

Daniele: é a medida do vértice.

Cármen: é a medida interna, não mas pode ser externa também.

Daniele: pode ser externa e interna.

$[\ldots]$

Pesquisadora 1:[...] Mas o que que é um ângulo? Vocês falaram nessa medida. A medida do ângulo. Quando os livros trazem, como que os livros trazem? O que que é ângulo? Na verdade tem várias definições para ângulos. Quando vocês falam, isso aqui é um ângulo, a gente tá falando de uma...

Leila: abertura. Algumas pessoas trabalham o ângulo como abertura entre 2 semi-retas, o quê.....vocês falaram o que, que se encontram, concorrentes. E ai alguns livros falam de abertura, outros livros falam da região, é a região compreendida entre duas semi-retas, [...] Um giro também. São diferentes formas de trabalhar a questão do ângulo.

(áudio pesquisa 1 - 3/8/2015.)

Em diferentes momentos deste episódio, verificamos que as professoras precisavam utilizar exemplos concretos para trabalhar o conceito de ângulo. Essa foi uma estratégia utilizada pelas professoras para a discussão deste conceito a partir do pensamento empírico. Mas as próprias professoras queriam ir além do conhecimento cotidiano que possuíam. Assim, percebemos que elas estavam organizando o pensamento abstrato concreto. Após essa discussão, voltamos para a definição de triângulo.

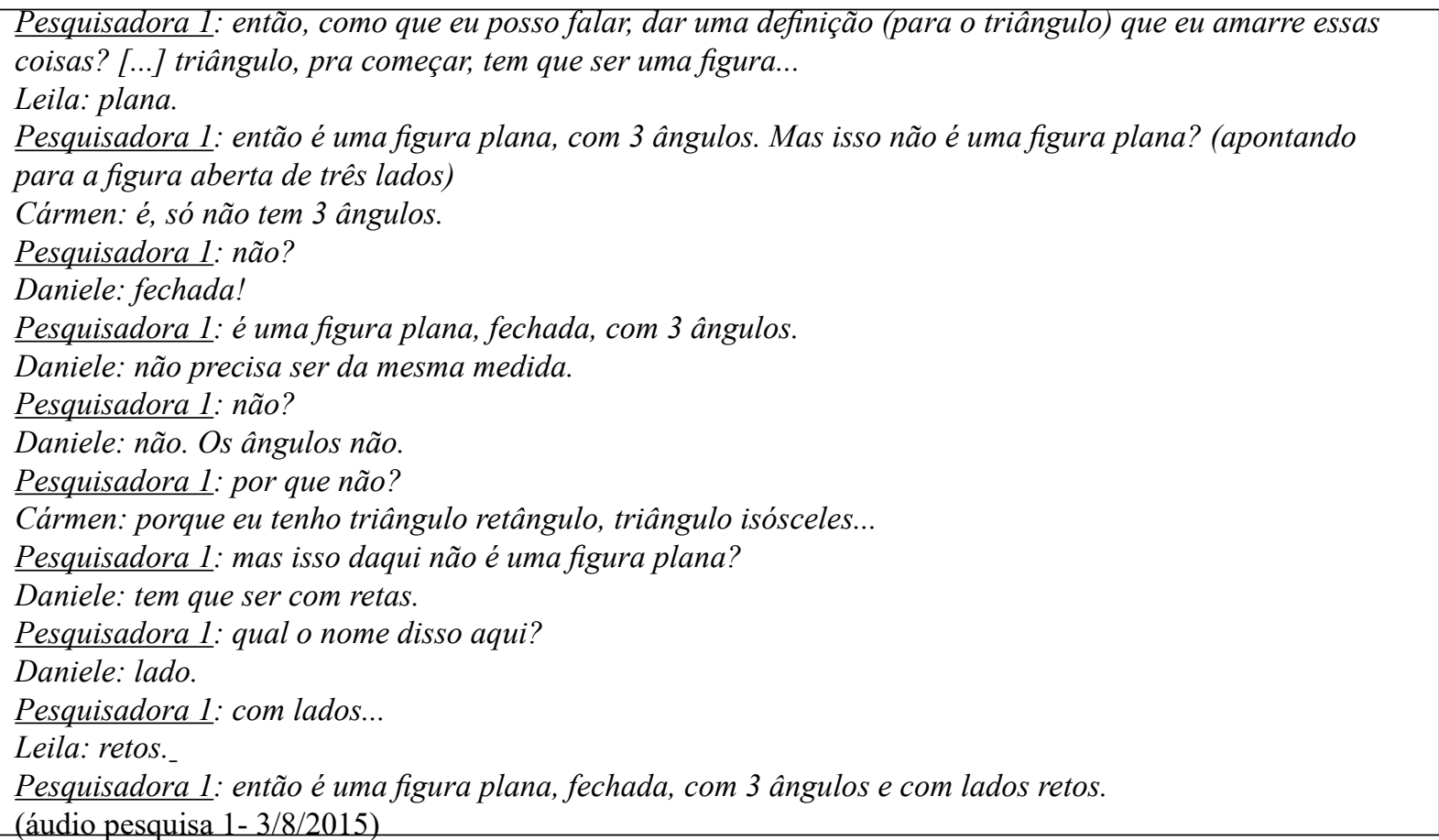

Os enunciados das professoras mostram a importância nos momentos de formação de contemplar situações de aprendizagem onde podem ser estabelecidas relações entre o concreto e o abstrato. Nesse sentido, os dados indicam elementos que aludem aos conceitos de abstrato- 
concreto e concreto-pensado, no campo dos conhecimentos geométricos. Ressaltamos que realizamos outras atividades e discussões que envolveram os conceitos de polígonos. Destacamos que essa discussão se deu no coletivo, a partir da necessidade das professoras em compreender os conhecimentos geométricos para organizar ações em suas salas de maneira mais adequada. Evidenciamos que essa ação reflete o que foi produzido no curso e que em diferentes momentos dessa atividade de formação coletiva, e que conforme nos aponta Lopes et. al (2016) os sujeitos foram levados a participar, a se colocar, a interagir com as outras professoras e com os objetos, pensando sempre em suas ações de ensino.

Os dados do encontro também nos levaram a problematizar nossas experiências pessoais de formação e das professoras participantes, bem como as deficiências oriundas de conhecimentos frágeis ou incorretos. Silva (2009) destaca que professores que possuem dificuldades em explicar conceitos geométricos, não conseguem abordar esses conteúdos de maneira adequada. Pavanello (2004) aponta que o problema vem da formação do professor e afirma que

As dificuldades de professores no reconhecimento de figuras geométricas planas, de seus elementos e propriedades, e, portanto, em atividades de classificação, indicam que o trabalho pedagógico realizado com eles nas diferentes instâncias de sua formação não Ihes permitiu elaborar devidamente seus conceitos sobre as figuras planas (PAVANELLO, 2004, p. 135).

Destacamos a importância de formação continuada que aborde esses assuntos, principalmente, no que diz respeito às discussões envolvendo conceitos geométricos. Nessa formação, tivemos outras discussões sobre definições e notamos como esse processo do abstrato concreto precisa ser explorado com professores. Nesse movimento permeado pela Atividade Pedagógica propiciamos momentos de reflexão, análise e apropriação individual de conhecimentos discutidos, tanto no âmbito de pensamento empírico como teórico (ARAUJO; MORAES, 2017). Outros exemplos podem ser vistos no trabalho de mestrado completo, elaborado por Souza, (2016b).

Ao longo do processo formativo as professoras realizavam reflexões escritas no ambiente moodle institucional. Na sequência, observamos uma das professoras sua percepção quanto aos conhecimentos trabalhados e a maneira pelo qual desenvolvemos nossas ações formativas.

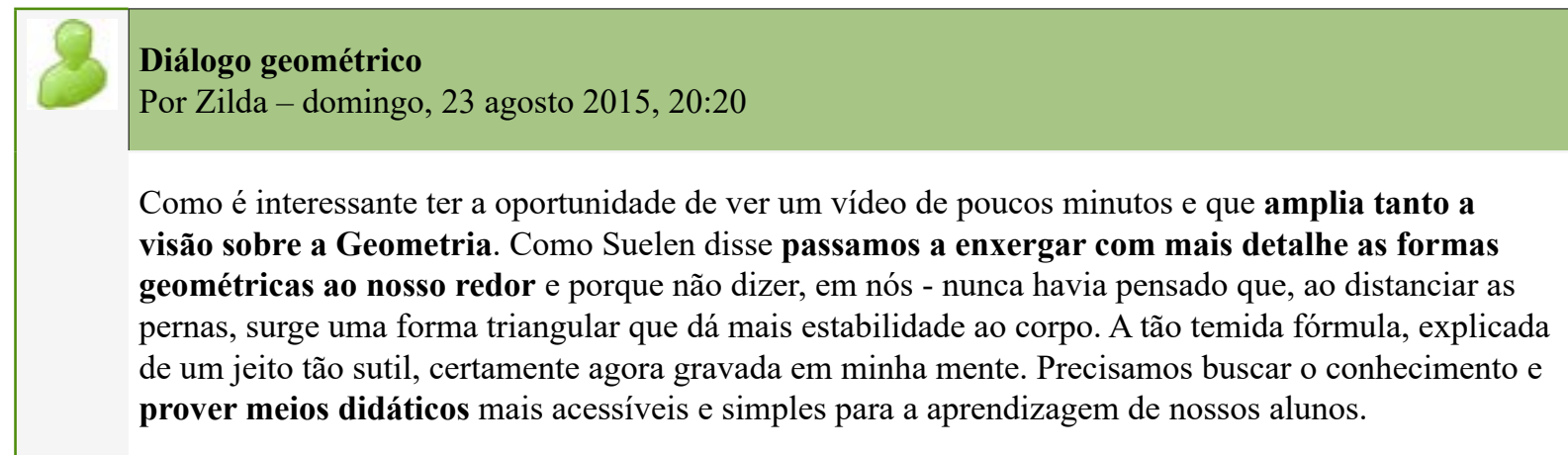

A fala de Zilda evidencia o processo reflexivo na qual estava se apropriando de conhecimentos teóricos no movimento do curso. É interessante destacar que ao final ela destaca a Atividade Pedagógica, pensar o conteúdo e instrumentos para abordar em sala de aula. Isso ressalta nosso processo formativo ancorado na Perspectiva Histórico-Cultural, na qual o professor em formação precisa pensar e agir sobre o seu fazer, que no caso é sua atividade de ensino.

\subsection{Episódio 2 - 0 que medimos?}

No segundo curso escolhemos o episódio de formação identificado por nós a partir da indagação: o que medimos? Essa questão esteve presente ao longo de alguns encontros e trazemos um recorte dos dados para evidenciar como a relação estabelecida entre os participantes e os formadores no coletivo levaram a indícios de compreensão de aspectos relacionados ao conhecimento de grandezas e medidas.

No encontro do dia 28/09/2015, as discussões estavam relacionadas com o livro de literatura infantil "Pedro e a lua" do autor Brière-Haquet. Após ambientação e leitura interpretativa do livro, a mestranda 2 iniciou um diálogo sobre o que poderia ser identificado na história quanto ao conteúdo 
de grandezas e medidas. As professoras relacionaram a comprimento, altura, tempo e destacaram que no texto evidenciava que Pedro era muito pequenininho.

Avaliando outras partes do livro para identificar possibilidades de trabalho com grandezas e medidas começaram com a imagem das casas (figura 5). A mestranda instiga as professoras que ao relacionarem os conteúdos fazem ligações com seus alunos, isso mostra que não há separação entre a discussão teórica e prática, mais ainda, que o professor em formação não se afasta de sua atividade principal que é a Atividade de ensino. Para abordar o conteúdo as professoras pensam em seus alunos, em suas ações no ato de ensinar, na Atividade Pedagógica. No diálogo a seguir, notamos como isso ocorreu na formação.

Figura 5 - Imagem livro Pedro e a Lua

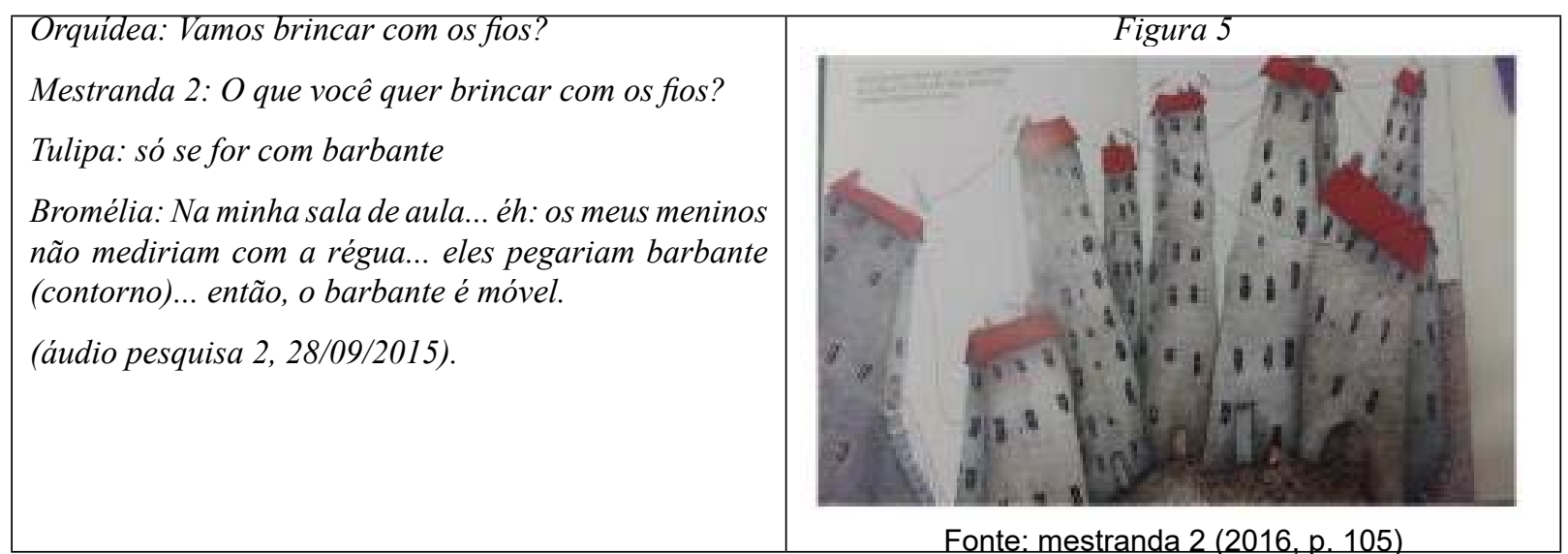

Fonte: mestranda 2 (2016, p. 105).

Segundo Souza (2016a, p. 107), "esses enunciados expressam a percepção das professoras diante da oportunidade criada pela situação-problema em torno dos fios discursivos contidos na imagem". Na formação já tinha acontecido discussões acerca de unidades de medida padronizadas e não padronizadas. Notamos como a professora Bromélia percebe a possibilidade do uso do barbante, ao invés do uso da régua. Na discussão ficou evidenciado que precisamos pensar em explorar diferentes instrumentos de medidas, padronizados ou não. Ressaltamos a necessidade de trabalhar com as relações entre o concreto e o abstrato a partir da fala da professora, mas entendemos que esse concreto deve ser o ponto de chegada, quando pensamos que essa ideia de medida precisa ser ampliada para um concreto pensado no âmbito do comprimento. Fica evidente também a necessidade de trabalhar o pensamento empírico e o uso de instrumentos para se conseguir uma reestruturação para a apropriação do pensamento teórico (DAVIDOV, 1988).

Na sequência, temos mais um diálogo no qual uma professora reflete sobre como poderia realizar uma abordagem próxima dos seus alunos do processo de medição. Na perspectiva HistóricoCultural essa mediação pode ser de um instrumento ou do próprio professor. Percebemos como as professoras pensam em articular o pensamento empírico, a partir da organização de escolha de um instrumento para a medição como no pensamento teórico, quando destaca que precisa pensar na medida padronizada. Essa última se constituindo como uma produção humana que precisa ser aprendida no ambiente escolar. Pensando em seus alunos, ela utiliza o menininho Pedro como unidade padrão de medida.

Orquídea: Dava pra pensar também... quantos menininhos são necessário para fazer a altura desse prédio? A
gente pode pegar ele como medida... ele a medidinha dele (fazendo com os dedos polegar e indicador o gesto)
ele que é tão pequeno... como a cidade é tão grandona... vamos ver quantos menininhos precisamos para fazer
um prédio desse? [...]
Iris: Até com os pequenininhos dá pra fazer em dois momentos... o primeiro momento quando você faz os
bonequinhos, e cola um em cima do outro até chegar lá em cima... e no segundo momento fazer ele entender que
aquilo é a mesma coisa que cinco centímetros... que faz de conta que é o menininho...que faz de conta... que faz
de conta (fazendo o gesto com a os dedos polegares e indicadores erguendo gradativamente o braço) ....aí ele
entende
(áudio pesquisa 2, 28/09/2015).


Notamos que nessa proposta dialógica adotada em nossas formações a atividade de ensino do professor ganha destaque. Ao participar de uma ação formativa dessa natureza sempre vincula com sua atividade principal que é o trabalho docente, o seu fazer, sua atividade de ensino (MOURA, 2010). Em vários momentos do curso isso fica evidenciado. O professor em seu momento de estudo sempre pensa em sua sala de aula, em seus alunos e em como poderia trabalhar o conteúdo tematizado.

Nesse mesmo encontro, as discussões levaram à seguinte pergunta: o que medimos? Registramos as diferentes respostas das professoras e estabelecemos um confronto das ideias apresentadas (fig. 6). Nossa proposta era ressaltar a diferença entre grandeza, medida, instrumento de medida e unidades de medidas.

Figura 6 - Tempestade de ideias sobre: o que podemos medir?

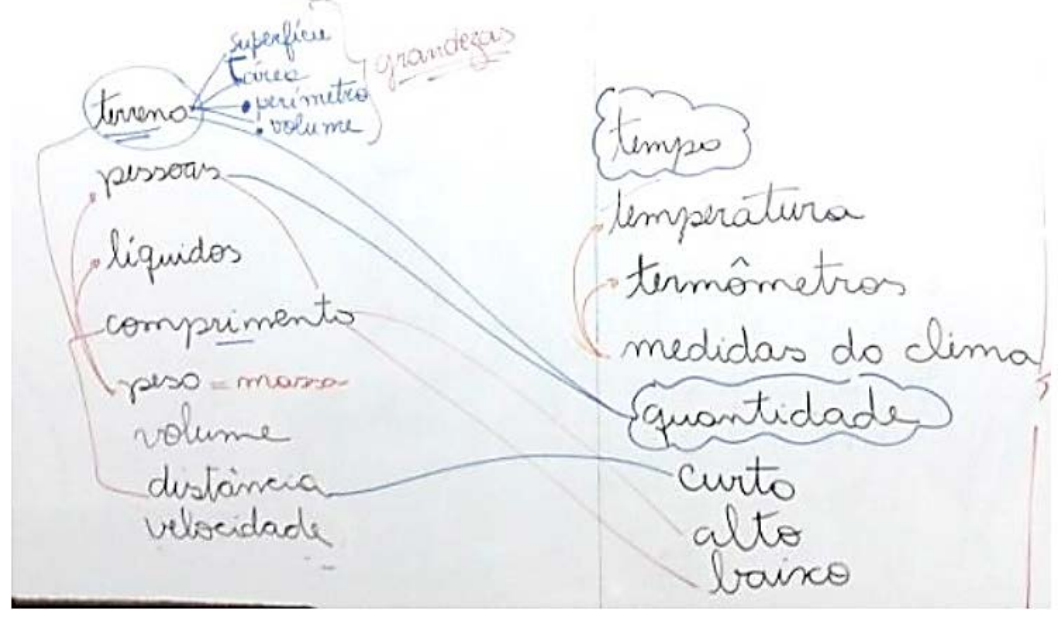

Fonte: pesquisa 2 (2016, p. 108).

Essas anotações no quadro serviram de base para identificarmos conhecimentos das professoras acerca das medidas e tentarmos diferenciar grandeza de medida, de instrumento e unidades de medida. Notamos que "a discussão estabelecida favoreceu a reflexão sobre a necessidade de distinguir objetos de grandeza, especificar o atributo com o qual está comparando, isto é, medir com o instrumento adequado" (SOUZA, 2016a, p. 109). Mais uma vez notamos a importância da coletividade para a discussão e apropriação de conhecimentos. Os diálogos, a seguir, mostram como provocamos as professoras a organizarem relações e fazer distinções quanto ao campo de medidas.

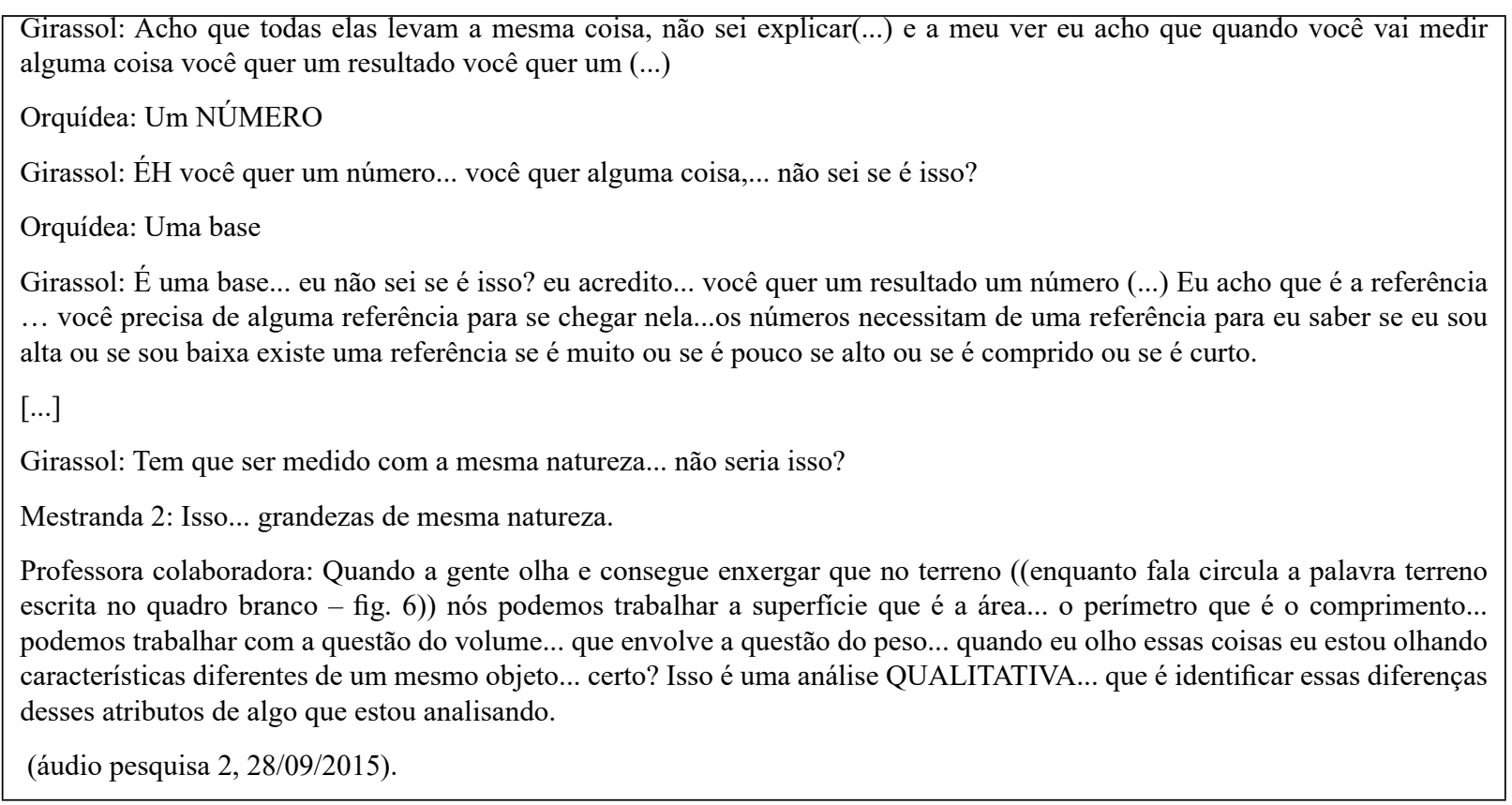


Destacamos que no diálogo anterioras professoras, Girassole Orquídea tentavam complementar suas falas na tentativa de enunciar a ideia base de medida. Percebemos que já se aproximam da definição encontrada em Caraça (1951, p. 29), em que "[...] medir consiste em comparar duas grandezas de mesma espécie". As provocações levantadas ampliaram as discussões mobilizandoas em busca de uma sistematização do conhecimento do conteúdo de grandezas e medidas.

Após essa sistematização, foi possível indicar que um mesmo objeto ou situação pode ser analisada de diferentes maneiras. Para isso, investigamos articulações do pensamento empírico e do conhecimento teórico e notamos que é importante definir sobre qual aspecto do objeto analisado iremos realizar a medida. Esse atributo é a grandeza ao qual desejo medir. Para medir, preciso estabelecer comparações e identificar qual unidade de medida é mais adequada, somente após estas escolhas podemos eleger um instrumento de medida e efetivamente medir. Os dados desse episódio apontam para os vários elementos inerentes aos conhecimentos de grandezas e medidas, mas que inicialmente ainda se apresentavam aos professores de modo confuso. Os conhecimentos dos professores estavam muito relacionados ao significado social de medida, conhecendo que existe diferença entre área, perímetro e outras grandezas, mas ainda focalizado no pensamento empírico, que valoriza a abstração pela generalização. No movimento formativo dessas professoras tentamos ir além, pensar sobre os conceitos, organizar as ideias levando a refletir sobre o conteúdo matemático grandezas e medidas e se apropriar do pensamento teórico (ROSA; MORAES; CEDRO, 2010). Não podemos afirmar que as professoras se apropriaram deste pensamento teórico, mas que criamos discussão coletiva de pensar sobre.

A partir das interações entre os sujeitos da formação, notamos uma melhor delimitação de noções como de grandezas, unidades de medidas e instrumentos. Outras discussões foram desenvolvidas durante o curso que possibilitaram o aprofundamento de conhecimentos relativos a cada elemento desse envolvido no eixo de grandezas e medidas. Nesse episódio, ainda podemos verificar como as professoras estabelecem relação do concreto abstrato e como se envolve num movimento de estudo no processo formativo que não se desvincula da sua atividade principal que é a atividade de ensino. Girassol, no recorte a seguir, exemplifica uma abordagem do conteúdo de grandezas e medidas em uma turma de quatro anos, destacando que participa da formação que a leva a pensar em sua atividade pedagógica.

Orquídea: Eu acho que a gente peca muito enquanto professora... assim eh:: eu tô me colocando nessa situação... porque realmente eh:: a gente aprende é com... é lá no início mesmo com as questões simples... mas, muitas vezes dentro da escola você acaba tendo que aprender a teoria... sabe? Então..., você tem que aprender que um centímetro é um centímetro, e ele está ali... e ele tem essa medida na régua ((faz o gesto com os dedos)) sabendo que poxa... eu posso medir com barbante, eu posso medir com menino... posso medir.. tendo a minha altura como referência... com o dedo... com o palmo... e a gente deixa de ter muito isso dentro de si, sabe? Desde o princípio, sabe? Nós aprendemos muito a::. caixinha... a teoria... eu falo isso da minha experiência enquanto aluna... CARACA.. Olha Só... eu posso fazer uma medida da porta fazendo assim... assim... assado... com meu corpo... com aquilo que eu tenho em casa... isso AGORA faz sentindo pra mim... mas para as crianças pode fazer sentido agora... entende? Não precisa demorar chegar a minha idade para entender tantas coisas, né? Uma vez que... pra eles... tudo se resolve muito mais facilmente (DIÁRIO DE CAMPO pesquisa 2, 28/09/2015).

A professora destaca o papel social do trabalho educativo, pensa na sua atuação como professora, e em sua experiência enquanto aluna. Destaca uma falha no processo educativo na perspectiva Histórico-Cultural, na qual deveria ajudar o sujeito a compreender e se apropriar dos conhecimentos produzidos pela humanidade. Isso a faz pensar em sua prática, a fazer diferente. Nossa percepção é que ela já está se apropriando de um conhecimento docente que pode a colocar em Atividade de Ensino, na qual o "professor deve gerar e promover a atividade do estudante [...] criar nele um motivo especial para a sua atividade: estudar e aprender teoricamente sobre a realidade" (MOURA et. al, 2016, p. 103).

\subsection{Episódio 3 - Discussões sobre o inteiro}

Ao analisarmos o terceiro curso relacionado às frações e seus significados, escolhemos um dos episódios de formação que apresenta uma discussão sobre o significado de inteiro e suas representações. Foi interessante observar nos dados como os professores participam de situações formativas que discutam de forma mais abrangente a noção de inteiro para se apropriar de novas representações. Em um dos encontros, iniciamos discussões a partir de uma série de situações problemas que abordavam diferentes significados de frações. Esclarecemos que exploramos 
frações como representações de números racionais positivos, visto que o foco foi o trabalho com professores que ensinam matemática nos anos iniciais. Após um momento de discussão coletiva entre os professores, produzidas em pequenos grupos, discutimos o problema do texto 2 (fig. 7). Essa questão gerou muitos debates, pois as professoras e o professor não concordavam que 0 inteiro fosse uma figura não convencional, elas relacionavam o inteiro com o círculo e não com parte de um círculo.

\section{Figura 7 - Problemas apresentados na formação}

Figura 7
Texto 2:
Considerando que o desenho abaixo corresponde a dois terços de uma figura inteira. Encontre a figura inteira.
Texto 3:
Lucas recebeu $\mathrm{R} \$ 150,00$ de mesada. Comprou um chinelo, uma camisa e um presente para sua mãe. Quando chegou em casa, Lucas
percebeu que ainda havia $\mathrm{R} \$ 50,00$ em sua carteira.
a) Como podemos representar em forma de fração as situações descritas acima. No texto 3, compare o valor gasto por
Lucas em relação ao valor que ele tinha anteriormente.
b) Apesar de estarem escritas da mesma forma, elas têm o mesmo significado? Quais diferenças você percebe entre eles?

Fonte: pesquisa 3 (2017).

Desde o momento em que os professores discutiam em duplas notamos que já se incomodavam com esse problema, inclusive indicando que estava errado. As formadoras precisaram participar das discussões mediando alguns questionamentos a fim de instigá-las sobre elementos inerentes ao problema. Na discussão uma professora fala: Não imaginava que pudesse ter um inteiro pela metade, desconstruí um conceito e aprendi novamente. Essa fala corrobora com a de outros professores, que consideravam impossível a representação de um inteiro - o todo - com figuras não usuais.

\footnotetext{
Pesquisadora: $O$ que vocês acharam do texto 2 ?

Prof. : esse desenho, deu dor de cabeça. (se referindo aos 2/3 da figura)

Professora V: Eu pensei o seguinte: a gente sempre pensa naquela coisa de que tem que ser tudo completinho (neste momento, outras vozes concordam com o que ela disse até aqui). [...] Só que eu posso pensar que o meu todo é algo como o cata-vento (ela foi ao quadro fazer o desenho do cata-vento com três hélices) [...] Eu insisto bastante nisso com os meus alunos, pra sair daquela de que o todo era tudo inteirinho... Eu posso pensar em qualquer coisa que me diz que isso aqui é dois de três (apontando para o cata-vento que desenhou no quadro).

Mestranda 3: mas o todo pode ser daquele jeito? O inteiro pode ser daquele jeito? (sobre o texto 2)

Prof. S: Pode

Mestranda 4: Mas o todo não tem que ser certinho, fechadinho, 'inteirinho'?

(Muito burburinho, até alguém dizer)

Prof. A: Eu achava também, até elas me trazerem uma luz. (se referindo à uma formadora).

Prof. M.: Eu compreendi, quase quinze anos lecionando que uma rosca com furo no meio é inteira. Ela continua sendo inteira mas até agorinha mesmo eu achava que ela estava faltando uma parte.

Mestranda F.: Então eu vou te contar um segredo: Até a gente começar o curso eu também achava isso. Eu só fui descobrir isso quando eu estava planejando com as meninas (se referindo às outras mestrandas) [...] Então nesse caso o nosso inteiro tem quantas partes? (voltando à pergunta)

Grupo: Três

Mestranda F.: Então qual a representação de fração que a gente teria aqui?

Professores: Dois terços

$[\ldots]$

Mestranda $C .:$ gente deixa eu só falar uma coisinha, na verdade quais observações que eu vi ao andar em meio a vocês. Nós já estamos tão bitolados com alguns conceitos que quando falamos de um semicírculo ele não poderia para nós representar o todo. O todo teria que ser o círculo completo. A professora Alê estava indignada no início e dizia: "Não, isso não pode ser um inteiro, eu não aceito!'”[...] Mas quero falar de duas professores em especial, elas estavam quase doidas. Ai eu cheguei e fiz uma pergunta a elas. Perguntei de modo que elas olharam de um outro ponto de vista. O que eu falei: Se eu digo que isso é dois terços, o que vocês entendem ser um terço? As duas responderam: "Metade dessa figura". [...] Se eu tenho dois terços o todo tem que ter quantas partes? Responderam as duas prontamente: "Três". Se está dito que tem duas partes eu preciso de quantas para completar as três?

Grupo: Mais uma
} 


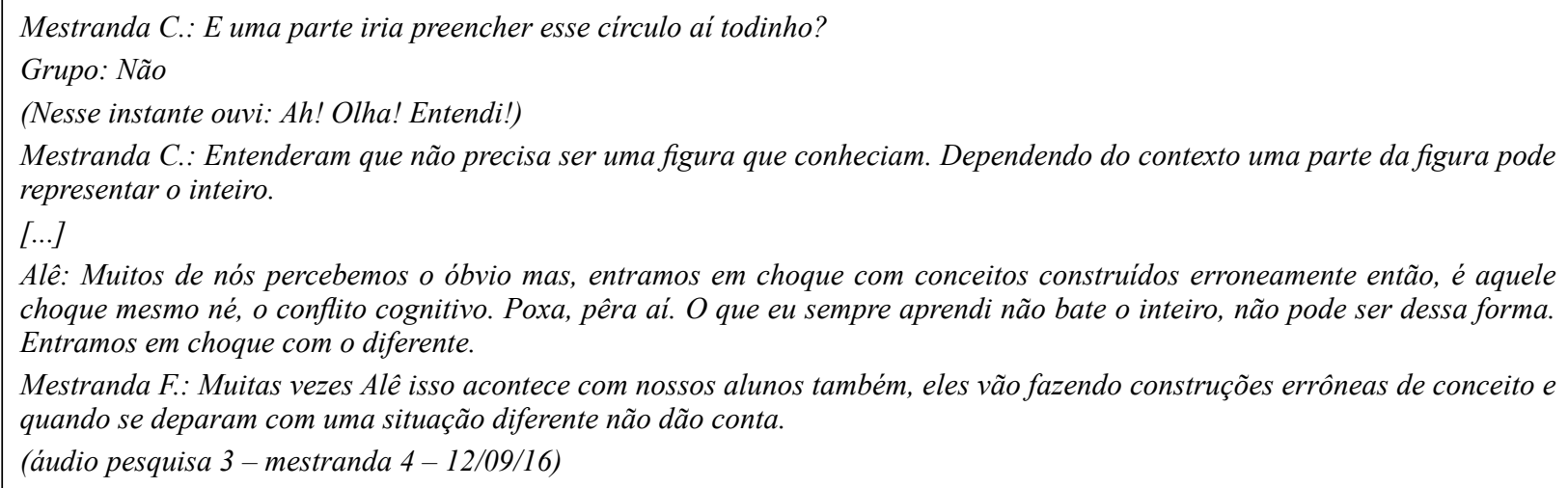

Destacamos que durante as duplas de discussão uma formadora aproveitou uma rosquinha do lanche que organizamos para a formação e fez uma provocação com as professoras, perguntando se a rosquinha estava inteira ou não. Elas perceberam que a rosquinha era inteira apesar de ter um furo no meio, inclusive destacou isso no diálogo de discussão sobre a atividade. Essa situação representa o pensamento empírico, pelo qual as professoras puderam estruturar o concreto pensado e explicar que podemos ter qualquer figura, mesmo que não seja a mais utilizada normalmente como o inteiro. Destacamos esse episódio visto que as professoras afirmaram em diferentes momentos do processo formativo que trabalhavam muito com a ideia de fração como parte-todo e o inteiro. Mas identificamos que este conhecimento ainda não estava apropriado em seu pensamento científico, tinha limitações ao que era superficial. Na nossa proposta de trabalhar na Perspectiva HistóricoCultural, precisamos estar atentas ao processo formativo, evidenciar o trabalho do professor em sua função principal que é a Atividade de Ensino. Para isto, o professor precisa de uma formação que o ajude a se apropriar de conhecimentos científicos. Notamos que o coletivo, a discussão e utilização de instrumentos contribuíram para a mediação entre os professores e o conhecimento matemático, que no nosso caso foi o de frações. Essa ação coaduna com a tese defendida por Gladcheff e Moura (2016, p. 825, grifos dos autores) de que

uma atividade de formação contínua de professores, na perspectiva da teoria histórico-cultural, a significação da atividade de ensino de matemática desenvolve-se nos sujeitos a partir das ações que realizam coletivamente para objetivar a aprendizagem teórica de conhecimentos matemáticos.

Essa aprendizagem teórica dos conhecimentos matemáticos relacionados ao inteiro e suas representações estiveram presentes nas discussões deste episódio e de outros durante o processo formativo. Quanto ao inteiro e sua representação analisamos a resposta da professora Alê (fig.8) e notamos que ela registra o círculo completo, o que não representa o que foi solicitado no problema. Em seguida, acrescenta seu processo de apropriação desse conceito com outro enfoque. $O$ que está de acordo com o que vimos no diálogo em sua explicação.

Figura 8 - Resposta da professora Alê ao problema 2

\begin{tabular}{|c|c|}
\hline 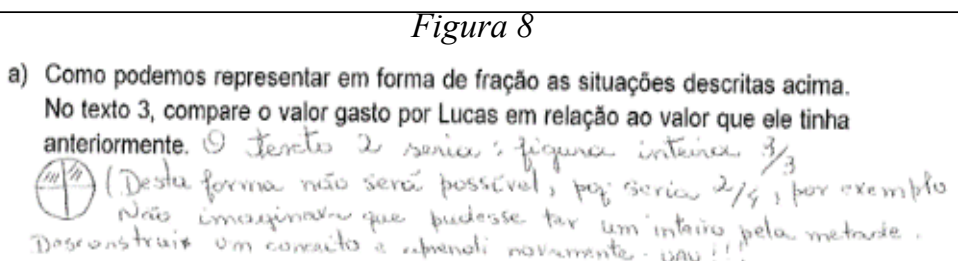 & $\begin{array}{l}\text { O texto } 2 \text { seria: figura inteira } 3 / 3 \text {. } \\
\text { Desta forma não será possível, } \\
\text { porque seria } 2 / 4 \text {, por exemplo. Não } \\
\text { imaginava que pudesse ter um inteiro } \\
\text { pela metade. Descontruí um conceito } \\
\text { e aprendi novamente. UAU! }\end{array}$ \\
\hline
\end{tabular}

Fonte: mestranda 3 (2017).

Essa visualização do inteiro contribuiu para a apropriação do conceito de fração. Está diretamente relacionada com a ideia de visualização de figuras geométricas. Estudo de Hershkowitz (1994) defende que a visualização, geralmente, se refere à habilidade de representar, transformar, gerar, comunicar e refletir sobre informação visual. Essa autora destaca que a imagem mental dos objetos geométricos perpassa a visualização. Percebemos que a imagem mental que os professores possuíam sobre figuras 'inteiras', não incluía figuras com reentrâncias. Essa situação 
evidencia a necessidade de utilizarmos figuras não protótipas, ampliando discussões com exemplos e contraexemplos. A visualização foi facilitada ao recorremos a diferentes exemplos: uma rosca, um pudim ou, até mesmo, uma fatia de bolo. Os professores compreenderam que o inteiro a ser fracionado pode assumir diferentes formas dependendo da situação.

Acreditamos que o processo formativo influenciou em ações e em práticas das professoras e professor participantes. O relato de experiência da professora Kássia enuncia uma ação desenvolvida por ela em relação ao trabalho de fração como parte-todo com uso de instrumentos diversos, discutidos no processo formativo. Na apresentação oral do relato, a professora destacou que modificou sua abordagem a partir do curso, pois antes só levava para a sala bolo ou pizza para a abordagem da ideia de fração como parte-todo.

[...] Após planejamentos, resolvemos iniciar com os alunos a ideia do todo e para que os alunos entendessem o
que é o todo, levei para a sala pães em diversos formatos (redondo com furo no meio, retangular, mini pãezinhos
em dois saquinhos para faze-los instiga-los sobre fração imprópria), garrafa com água, papel higiênico, um pode
de lápis de cor e uma caixa de bombom.
Após perguntá-los sobre o que todos aqueles elementos tinham em comum, uma aluna disse que podiamos
repartir tudo o que estava sobre a mesa. A partir dai fui mostrando que todos aqueles itens estavam inteiros,
inclusive a caixa de bombom. Peguei um pão retangular e enquanto mostrava as possibilidades de se repartir, E.
9licenciando) foi explicando aos alunos sobre a "justiça" de se repartir em partes iguais. Cortei então o pão ao
meio e fui perguntando como representaria a fração se eu comesse uma parte daquele pão. Deixei que pensassem
e registrassem no quadro. Deixei uma metade intacta e fracionei novamente a metade da metade. A partir daí
pergunte novamente como seria a representação fracionária. Após alguns argumentos e registros interessantes,
uma aluna lá do fundo gritou que uma parte daquela divisão seria 1/4 mesmo que eu não tivesse fracionado a
outra metade. Após essa descoberta, os alunos foram participando mais e se arriscando mais... até que fracionei
o suficiente para que todos pudessem comer do pão. Durante 3 aulas seguidas fui fracionando e dando aos
alunos as partes fracionadas, inclusive os minis pãezinhos, quando, ao passar pela segunda vez para distribui-
los, precisei abrir o outro pacotinho e assim, questionei-os sobre como seria representar o que acabei de fazer.
Na prática entenderam que eu utilizei um pacote inteirinho do pãozinho, mas não usei o outro por completo.
Mas quando viam a representação tinham dúvidas sobre os números registrados. Indo e vindo com as anotações
e desenhos no quadro os alunos foram entendendo não só o conceito de inteiro, mas também o representa o
numerador, o denominador, frações equivalentes, parte-todo, além do conceito da divisão e medida.
(relato professora no moodle)

Nesse terceiro episódio de formação identificamos o mesmo movimento do processo de formação docente sinalizado nas outras ações, no qual os professores estudam nos cursos para aprender determinado conteúdo e se apropriar do conceito envolvido, para pensar no seu trabalho de ensinar e, assim, se apropriar de conhecimentos matemáticos e didáticos inerentes ao trabalho do professor. Novamente notamos que o processo formativo coletivo favoreceu o encaminhamento das ações e a integração dos participantes. Eles assumiram a formação como processo amplo e participativo. Analisamos a natureza do trabalho docente, conforme nos aponta Franco e Longarezi (2011), sua docência, seu objeto de ensino que são conhecimentos matemáticos, e ampliamos discussões acerca de suas necessidades pessoais e profissionais. As pesquisas de mestrado relacionadas a esta formação estão em andamento, mas já existem trabalhos publicados em eventos sobre esse movimento (LOPES; SILVA, 2017; SANTOS; CÔCO, 2017; RISSO; CÔCO; SILVA, 2017).

\section{CONSIDERAÇÕES FINAIS}

Neste artigo, apresentamos análises de dados produzidos em três experiências de formação continuada de professores, em cursos de extensão ofertados por um Instituto Federal. Tivemos por objetivo evidenciar apropriação de conhecimentos matemáticos e práticas educativas enunciadas por professores em atividades de formação continuada, desenvolvida a partir da Perspectiva HistóricoCultural. Notamos que os episódios de formação selecionados nas diferentes ações desenvolvidas, mostram o processo de discussão dos conceitos que possibilitou um aprofundamento de conhecimentos matemáticos dos participantes. Os exemplos sinalizam que as situações de estudos trabalhadas na formação ofereceram condições aos professores para elaborarem reflexões que remetem a ideia de concreto pensado. Pontuamos que esses processos formativos evidenciaram movimentos dos participantes relacionados tanto ao pensamento empírico como ao processo de apropriação do pensamento teórico discutidos por Davidov (1988). 
Nesse processo de interação, os professores participantes assim como os formadores, mestrandos e licenciandos envolvidos, nas três experiências de formação continuada, foram mobilizados a entrarem em atividades de estudos a partir de suas necessidades advindas do trabalho de ensinar, seja na formação ou na sala de aula de cada professor. As discussões foram motivas por um motivo pessoal que as professoras trouxeram de sua docência, de seu trabalho, e que se transformou num motivo coletivo, compartilhado pelos envolvidos. Assim, realizaram ações e operações que possibilitaram o acesso ao conhecimento científico, de modo que se apropriaram da produção humana desenvolvida no campo da matemática. Sabemos que essas apropriações são diferentes para cada sujeito, mas as ações de formação organizadas a partir dessas referências da perspectiva Histórico-Cultural apontam essas possibilidades formativas.

Notamos uma necessidade de reflexões mais aprofundadas dos conhecimentos matemáticos científicos, para que os envolvidos pudessem superar as noções cotidianas que, em alguns casos, estavam limitadas. Ao longo do processo, ficou claro que as professoras e professores envolvidos relacionavam o que aprendiam com sua atividade principal, essa relação está de acordo com a Perspectiva Histórico-Cultural que adotamos. Assim, compreendemos que precisamos cada vez mais entender a formação docente como um exercício para a docência e como uma Atividade, na qual a coletividade encaminha as ações desenvolvidas. 


\section{REFERÊNCIAS}

ARAÚJO, E. Da formação e do formar-se: a atividade de aprendizagem docente em uma escola pública. Tese de Doutorado em Educação, Universidade de São Paulo, São Paulo, 2003.

ARAUJO, E. S.; MORAES, S. P. G. de. Dos princípios da pesquisa em Educação como Atividade. In: MOURA, M. O. de. (Org.). Educação Escolar e pesquisa da Teoria Histórico-Cultural. São Paulo: Edições Loyola, p. 47-70. 2017.

ASBAHR, F. da S. F. "Por que aprender isso, professora?" Sentido pessoal e atividade de estudo na Psicologia Histórico-Cultural. 220f. Tese (Doutorado) - Instituto de Psicologia da Universidade de São Paulo. 2011.

CARAÇA, B. de J. Conceitos fundamentais da Matemática. Lisboa: Lisboa Editora, 1951.

CEDRO, W. L. O motivo e a atividade de aprendizagem do professor de matemática: uma perspectiva Histórico-Cultural. Tese (Doutorado em Educação) Programa de Pós-Graduação em Educação. Universidade de São Paulo, 2008.

DAMIANI, M. F. Sobre pesquisas do tipo intervenção. ENCONTRO NACIONAL DE DIDÁTICA E PRÁTICAS DE ENSINO, 16.. Campinas, 2012. Anais..., Universidade de Campinas, Campinas, 2012.

DAVIDOV, V. La enseñanza escolar y el deserrollo psíquico. Traducido del ruso por Marta Shuare. Moscu: Editorial Progresso, 1988.

DUARTE, N. Os conteúdos escolares e a ressurreição dos mortos: contribuição à teoria histórico-crítica do currículo. Campinas, SP: Autores Associados, 2016.

FRANCO, P. L. J.; LONGAREZI, A. M. Elementos constituintes e constituidores da formação continuada de professores: contribuições da teoria da atividade. Educação e Filosofia. Uberlândia, v. 25, n. 50, p. 557-582, jul./dez. 2011.

GATTI, B. A.; BARRETTO, E. S. de. Professores do Brasil: impasses e desafios. Brasília: UNESCO, 2009.

GLADCHEFF, A. P.; MOURA, M. O. de. A significação da atividade de ensino de matemática em uma atividade de formação. ENCONTRO NACIONAL DE DIDÁTICA E PRÁTICA DE ENSINO, 18. Cuiabá. Anais... Cuiabá, 2016.
HERSHKOWITZ, R. Visualização em geometria as duas faces da Moeda. Boletim GEPEM, Rio de Janeiro: o grupo, n. 32, ano XVIII, p. 45-61, 1994.

LOPES, A. F.; SILVA, S. A. F. da. Frações e o significado parte-todo por professores dos anos iniciais em formação docente: discussões sobre o inteiro. SEMINÁRIO NACIONAL DE HISTÓRIAS E INVESTIGAÇÕES DE/EM AULAS DE MATEMÁTICA, 6. 2017, Campinas, Anais..., Campinas, 2017.

LOPES, A. R. L. V. et al. Trabalho coletivo e organização do ensino de matemática: princípios e práticas. Zetetiké. FE/Unicamp \& FEUFF, v. 24, n. 45, p. 13-28, jan/abr-2016.

LOPES, A. R. L.V. A aprendizagem docente no estágio compartilhado. Tese de Doutorado em Educação, Universidade de São Paulo, São Paulo, 2004.

MARSIGLIA, A. C. G. (Org.) Pedagogia histórico-crítica: 30 anos. Campinas: Autores Associados, 2011.

MARTINS, L. M. A formação social da personalidade do professor. um enfoque vigotskiano. Campinas, SP: Autores Associados, 2015.

MARX, Karl. Capítulo VI (inédito), O Capital, Livro I. São Paulo, Ciências Humanas, 1978.

MORETTI, V. D. Professores de matemática em Atividade de ensino. Uma perspectiva histórico-cultural para a formação docente. Tese (Doutorado em Educação). Faculdade de Educação - Universidade de São Paulo, São Paulo, 2007.

MORETTI, V. D.; MOURA, M. O. de. Professores de matemática em atividade de ensino: contribuições da perspectiva histórico-cultural para a formação docente. Ciência \& Educação, v. 17, n. 2, p. 435450, 2011.

MOURA, M. O. de. A atividade de ensino como unidade formadora. Bolema, Rio Claro (SP), ano II, $\mathrm{n}$. 12, p. $29-43,1996$.

O educador matemático na coletividade de formação: uma experiência com a escola pública. (Tese de livre-docência) - Faculdade de Educação da Universidade de São Paulo, 2000.

. A atividade de ensino como ação formadora. In CASTRO, A. D. de; CARVALHO, A. M. P. de. Ensinar a ensinar: didática para a escola fundamental e média. São Paulo: Cengage Learning, 2012.

MOURA, M. O. de. et. al (Org.). A atividade pedagógica na teoria histórico-cultural. Brasília: Liber Livros, 2010. 
MOURA, M. O. de. et al. A atividade orientadora de ensino como unidade entre Ensino e Aprendizagem. In: MOURA, M. O.de (Org.). A atividade pedagógica na teoria histórico-cultural. Campinas/SP: Autores Associados, 2016.

PAVANELLO, R. M. A geometria nas séries iniciais do ensino fundamental: contribuições da pesquisa para o trabalho escolar. In: PAVANELLO, R. M. (Org.). Matemática nas séries iniciais do ensino fundamental: a pesquisa e a sala de aula. São Paulo: SBEM, p.129-143. 2004.

RADFORD, L. Mathematics and Mathematics classroom activity through the lens of a metaphor. In IORI: M. (Ed.). La Matematica e la sua Didattica/ Mathematics and Mathematics Education. In occasion of the 70 years of Bruno D'Amore. Bologna: Pitagora Editrice, p.439-446. 2016.

RIGON, A. J.; ASBAHR, F. da S. F.; MORETTI, V. D. Sobre o processo de Humanização. In: MOURA, M. O. de (org.). A atividade pedagógica na Teoria Histórico-Cultural. 2ed. Campinas/SP: Autores Associados, 2016.

RISSO, F. B.; CÔCO, D.; SILVA, S. A. F. da. Uso de materiais manipuláveis envolvendo frações e suas contribuições em formação de professores dos anos iniciais. SEMANA DE MATEMÁTICA DO IFES, 6., Vitória, Anais..., Vitória, 2017.

ROSA, J. E. da; MORAES, S. P. G. de; CEDRO, W. L. A formação do pensamento Teórico emu am Atividade de Ensino de Matemática. In: In: MOURA, M. O. de (Org.). A atividade pedagógica na Teoria Histórico-Cultural. 2 ed. Campinas/SP: Autores Associados, 2016.
SANNINO, A. Activity theory as an activist and interventionist theory. Theory \& Psychology, v. 21, n.5, p.571-597, 2011.

SANTOS, R. M. M.; CÔCO, D. Formação de professoras dos anos iniciais sobre frações: uma experiência à luz da perspectiva Histórico-Cultural. SEMANA DE MATEMÁTICA DO IFES, 6. Vitória, Anais..., Vitória, 2017.

SAVIANI, D. Pedagogia Histórico-Crítica: primeiras aproximações. São Paulo: Autores Associados, 2008.

Formação de professores: aspectos históricos e teóricos do problema no contexto brasileiro. Revista Brasileira de Educação, v. 14, n. 40, p. 143-155, jan./abr. 2009.

SILVA, S. A. F. Aprendizagens de professoras num grupo de estudos sobre matemática nas séries iniciais. Tese (Doutorado em Educação) - Centro de Educação, Universidade Federal do Espírito Santo, 2009.

SOUZA, M. C. Conhecimentos de grandezas e medidas de Professoras dos anos iniciais a partir da literatura Infantil. Dissertação (Mestrado em Educação de Ciências e Matemática) Programa de Mestrado em Educação em Ciências e Matemática. Instituto Federal do Espírito Santo, 2016a.

SOUZA, R. R. (Re)Construção de conceitos geométricos por professoras dos anos iniciais em formação continuada. Dissertação (Mestrado em Educação de Ciências e Matemática) Programa de Mestrado em Educação em Ciências e Matemática. Instituto Federal do Espírito Santo, 2016b. 